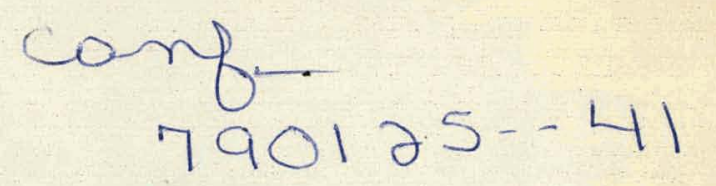

CONTROL OF BERYLLIUM-7

IN

LIQUID LITHIUM

R. P. Anantatmula, W. F. Brehm,

D. L. Baldwin and J. L. Bevan

December 1978

This repoit was prepared as an aciount of work
sponsored by the United States Government. Neither the
United States nor the United States Department of
Energy, nor any of their employees, nor any of their
contractors, subcontractors, or their employees, makes
any warranty, express or implied, or assumes any legal
liability or responsibility for the accuracy, completeness
or usefulness of any information, apparatus, product or
process disclosed, or represents that its use would not
infringe privately owned rights.

First Topical Meeting on Fusion

Reactor Materials

January 29-31, 1979

Miami Beach, Florida

HANFORD ENGINEERING DEVELOPMENT LABORATORY Operated by Westinghouse Hanford Company, a subsidiary of Westinghouse Electric Corporation, under the Department of

Energy Contract No. EY-76-C-14-2170

COPYRIGHT LICENSE NOTICE

By acceptance of this article, the Publisher and or recipient acknowledges the U.S. Government's right to retain a nonexclusive, royalty-free license in and to any copyright covering this paper. 


\section{DISCLAIMER}

This report was prepared as an account of work sponsored by an agency of the United States Government. Neither the United States Government nor any agency Thereof, nor any of their employees, makes any warranty, express or implied, or assumes any legal liability or responsibility for the accuracy, completeness, or usefulness of any information, apparatus, product, or process disclosed, or represents that its use would not infringe privately owned rights. Reference herein to any specific commercial product, process, or service by trade name, trademark, manufacturer, or otherwise does not necessarily constitute or imply its endorsement, recommendation, or favoring by the United States Government or any agency thereof. The views and opinions of authors expressed herein do not necessarily state or reflect those of the United States Government or any agency thereof. 


\section{DISCLAIMER}

Portions of this document may be illegible in electronic image products. Images are produced from the best available original document. 
CONTROL OF BERYLLIUM-7 IN LIQUID LITHIUM.

R. P. Anantatmula, W. F. Brehm, D. L. Baldwin and J. L. Bevan Hanford Engineering Development Laboratory

\section{ABSTRACT}

Radiation fields created by the production of ${ }^{7} \mathrm{Be}$ in lithium of the Fusion Materials Irradiation Test (FMIT) Facility can be sufficiently high to prevent contact maintenance of system components:- Preliminary experiments have shown that ${ }^{7} \mathrm{Be}$ will adhere strongly to the FMIT piping and components and a good control method for ${ }^{7} \mathrm{Be}$ must be developed. The initial experiments have been conducted in static stainless steel capsules and a Modified Thermal Convection Loop (MTCL). The average lithium film thickness on stainless steel was found to be $11 \mu \mathrm{m}$ in the temperature range $495^{\circ}-577^{\circ} \mathrm{K}$ from the capsule experiments. The short-term experiments showed that ${ }^{7} \mathrm{Be}$ migrates to the capsule wall and the long-term ex-periment indicated that ${ }^{7} \mathrm{Be}$ actually penetrates into the stainless steel wall. The diffusion coefficient for ${ }^{7} \mathrm{Be}$ in stainless steel at $543^{\circ} \mathrm{K}$ was calculated to be $5.31 \times 10^{-15} \mathrm{~cm}^{2} / \mathrm{sec}$. The cold leg of the MTCL picked up much of the ${ }^{7} \mathrm{Be}$ activity: released into the-loop.. The diffusion trap, located in the cold leg of the MTCL, was ineffective in removing ${ }^{7} \mathrm{Be}$

from lithium, at the very slow flow rates $\left(<3.79 \times 10^{-4} \mathrm{~m}^{3} / \mathrm{s}\right)$ used in the MTCL. Pure iron has been shown to be superior to cobalt and nickel as a getter material for ${ }^{7} \mathrm{Be}$.

INTRODUCTION

Beryllium-7 will be produced in the lithium target of the FMIT facility by the ir.teraction of the deuteron beam with lithium by the two reactions ${ }^{7} \mathrm{Li}(d, 2 n){ }^{7} \mathrm{Be}$ and $6 \mathrm{Li}(d, n){ }^{7} \mathrm{Be}$. This nuclide has a half $-1 \mathrm{ife}$ of 53 days and: emits a $0.48 \mathrm{MeV}$ gamma radiation. Previous estimates $\left({ }^{1}\right)$ have shown that an equilibrium concentration of $2.59-\times 10^{15} \mathrm{~Bq}$ ( $/ 0,000$ curies) of ${ }^{7} \mathrm{Be}$ will be present in FMIT lithium.- - This is equivalent to a concentration of approximately $1.11 \times 10^{9} \mathrm{~Bq} / \mathrm{gm}$ of FMIT lithium and a chemical concentration of $0.25 \mathrm{ppm}$. Concentrations of ${ }^{7} \mathrm{Be}$ of this magnitude can lead to radiation fields of over $5.16 \times 10^{-3}$ coulomb $/ \mathrm{kg} \cdot \mathrm{hr}(20 \mathrm{R} / \mathrm{hr})$. near FMIT piping and components, more than two orders of magnitude too high for easy contact repair 
and maintenance. A recent upper limit calculation of equilibrium concentration of ${ }^{7} \mathrm{Be}$ in FMIT lithium yielded $2.48 \times 10^{16} \mathrm{~Bq}$, which is approximately ten times the previous estimate. Therefore, the need to understand the transport of ${ }^{7} \mathrm{Be}$ in lithium and to eventually control the spread of the nuclide in the FMIT system has been realized.

A development program has been started recently to -identify $7 \mathrm{Be}$ transport and adherence. to metal surfaces in the FMIT temperature range.: Also incorporated in the program are studies to remove ${ }^{7} \mathrm{Be}$ - from lithium by cold trapping, coprecipitation with non-radioactive beryllium, and selective' deposition on materials (trapping).

The present paper describes the results obtained from ${ }^{7} \mathrm{Be}$ adherence itests from static capsule studies, and preliminary results on ${ }^{7} \mathrm{Be}$ transport in lithium from MTCL experiments.

\section{EXPERIMENTAL PROC.EDURE}

The lithium needed for the experiments was transferred from $: a: 0: 21-\mathrm{m}^{3}$ 1ithium drum to a $0.0038 \mathrm{~m}^{3}$ stainless steel tank through a nicke\} filter. The first set of capsule experiments was performed with lithium in stainless steel capsules, without any ${ }^{7} \mathrm{Be}$, to determine the lithium film thickness on stainless steel as a function of temperature in the FMIT temperature range. For the second series of capsule experiments, the molten lithium in the static capsules was charged with ${ }^{7} \mathrm{Be}$ to study the ${ }^{7} \mathrm{Be}$ adherence to stainless steel walls and transport in static lithium. The MTCL experiments were designed to understand the ${ }^{7}$ Be transport in slowly flowing 1 ithium and to analyze the effectiveness of the diffusion trap and deposition. samples to remove ${ }^{7} \mathrm{Be}$ from 1 ithium.

\section{a) Capsule Experiments}

The capsules were Type 304 stainless steel, $0.019 \mathrm{~m}\left(0.75^{\prime \prime}\right) 0.0$. and $0.017 \mathrm{~m}\left(0.68^{\prime \prime}\right)$ I.D.. Each capsule was approximately $0.42 \mathrm{~m}\left(16.5^{\prime \prime}\right)$ long and fitted with a Swagelok* union at one end and the other end welded shut. The capsules were cleaned internally by polishing with emery paper before welding, and cleaned with trichloroethane, acetone and ethanol subsequent - to the welding operation. As shown in Figure 1 , the capsules were heated 
in a quartz tube wrapped with a heater element. The temperature of the capsules was controlled to within $\pm 2^{\circ} \mathrm{K}$ over the entire length:

Molten lithium at $523^{\circ} \mathrm{K}$ was drained into the capsules preheated to $523^{\circ} \mathrm{K}$. from the stainless steel reservoir inside an argon glove box. The glove box was flushed with dry argon 5 or 6 times. to remove residual nitrogen and reduce the humidity, prior to filling the capsules with lithium. An analysis of the glove box atmosphere indicated no nitrogen. . The lithium. in the capsule appeared bright, without any discoloration, indicating no reaction with the glove box atmosphere.

${ }^{7}$ Be for the experiments was obtained from Oak Ridge National Laboratory (ORNL). Using a standard procedure recommended by ORNL, the ${ }^{7} \mathrm{Be}$ needed for the capsule experiments was converted to its nitrate. $\cdots$ An aliquot of the salt was pipetted onto a series of stainless steel pianchettes and dried. The nitrate was then ignited at $873^{\circ} \mathrm{K}$ to form the oxide. Each planchette was then bottled individually and counted by gamma spectroscopicanalysis (GSA). A single planchette was then wrapped with a.stainless steel wire to the center of the thermocouple tube and inserted into the capsule.

At the end of each run, the capsule was drained in the grove box into. a small stainless steel reservoir. The planchette and the drained lithium were counted for ${ }^{7} \mathrm{Be}$ activity by GSA. The capsule was then sectioned into several pieces and the lithium film from each piece dissolved in methanol/ water baths and the solution and the capsule piece counted for ${ }^{7} \mathrm{Be}$ activity by GSA. Aliquots of solution were subsequently_analyzed for lithium by Atomic. Absorption Spectroscopy.

\section{b) MTCL Experiments}

The MTCL is schematically illustrated in Figure 2. The vertical and

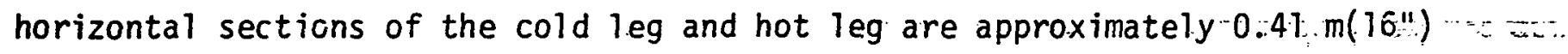
and $0.36 \mathrm{~m}\left(14^{\prime \prime}\right)$ respectively: Tackwelded staintess. steel pins were used to secure the deposition samples to the hot and cold leg thermocouple tubes: The samples were of iron $(99.64 \%)$, cobalt $(99.88 \%)$ and nickel $(99.98 \%)$, $0.025 \mathrm{~m} \times 0.01 \mathrm{~m}$, with thicknesses ranging from $1.27 \times 10^{-4} \mathrm{~m}$ for iron to 
$2.54 \times 10^{-4} \mathrm{~m}$ for nickel to $6.35 \times 10^{-4} \mathrm{~m}$ for cobalt. A diffusion cold trap was provided at the bottom of the cold leg. Due to the high surface tension and low. density of lithium at. FMIT operating temperatures,.. a linear... induction pump $\left(<3.79 \times 10^{-4} \cdot \mathrm{m}^{3} / \mathrm{s}\right)$ was used to aid the thermal convection flow; hence the namie MTCL. After initially heating the MTCL to a uniform temperature above $543^{\circ} \mathrm{K}\left(270^{\circ} \mathrm{C}\right)$, a temperature gradient of $54^{\circ} \mathrm{K}$ between the hot leg $\left(543^{\circ} \mathrm{K}\right)$ and the cold leg $\left(489^{\circ} \mathrm{K}\right)$, close to that of the FMIT temperature gradient, was maintained by providing a constant heat input to the hot leg and cooling the cold leg by blowers. The pump had to be operated at a very. low power input to maintain the temperature gradient.

Lithium flow at a very small rate was established from the hot leg through the pump to the cold leg.

For the MTCL experiments, ${ }^{7} \mathrm{Be}$ embedded in the lithium target material (probably in nitride form) was introduced in the upper part of the hot leg in the stagnant lithium. The loop was filled with lithium from the reservoir by evacuating the MTCL and applying $3.4 \times 10^{4}$ pascals ( 5 psi) argon pressure on the reservoir. While the MTCL was operating, gamma counting of the loop was performed by feeding the count output from a $\mathrm{NaI}$ detector into a computerized multichannel analyzer. "At the com-

pletion of the run, lithium from the MTCL was drained under argon pressure, and the drained ithium was gamma-counted by GSA, similar to the capsule experiments. A Germanium-Lithium detector was used in conjunction with the multichannel analyzer to analyze the 7 Be activity remaining on the deposition samples and the MTCL piping.

RESULTS AND DISCUSSION

\section{a) Capsule Experiments}

As mentioned earlier, the first set of experiments was aimed at determining the lithium film thickness on drained stainless steel surfaces. Four runs were made for this set of experiments. The capsules were maintained at $515^{\circ}, 537^{\circ}, 495^{\circ}$ and $571^{\circ} \mathrm{K}$ respectively for approximately 24 hours. At the end of each run, the straight section of each. capsule was cut into three pieces and each piece analyzed for lithium concentration along the length of the tube. The results from the four runs are reported in Table. 1. 
As can be seen from the table, the 1ithium film thickness ranges from $8.4 \mu \mathrm{m}$. to $12.3 \mu \mathrm{m}$ in the temperature range $495^{\circ}-571^{\circ} \mathrm{K}$. Cowles and Pasternak (2) report that pure lithium will not wet stainless steel until $673^{\circ} \mathrm{K}$, and the wetting temperature for impure lithium is $755^{\circ} \mathrm{K}$. However, the phenomenon of wetting is not only a function of temperature, but also a function of time at a given temperature, where the contact angle between the liquid-and the solid, in general, decreases with increasing time(3). Furthermore, the wetting temperature is raised by the presence of oxide film on a- metal surface. The stainless steel capsules used in the present investigations were cleaned. thoroughly to minimize the wetting problem from the oxide film.- In our experiments we have not detected any globules of lithium sticking to the straight surface of the capsule to introduce an error in the film thicknes calculation. However, we have made the assumption that the lithium film was distributed uniformly over the entire surface area of the capsule section examined.

The average film thickness from all four runs was $11.0 \mu \mathrm{m}$. in the temperature range $495^{\circ}-571^{\circ} \mathrm{K}$. - Because of its high surface tension and low density, lithium could not be poured from one capsule to another at $463^{\circ} \mathrm{K}$; precluding film thickness measurement at that temperature. At all the remaining temperatures of investigation, the top capsule had to be tapped to start the lithium flow into the bottom capsule, again due to the low density and high surface tension of lithium.

The second set of experiments was performed with ${ }^{7} \mathrm{Be}$ in oxide form. As before, four runs were made for these experiments." For Run 5 ; the planchette containing $4.03 \times 10^{7} \mathrm{~Bq}(1.09 \mathrm{mCi})$ of ${ }^{7} \mathrm{Be}$ was heated in the capsule containing lithium to $543^{\circ} \mathrm{K}$ and kept overnight for a period of 17 hours. Then the capsule was cut into 9 pieces and analyzed for ${ }^{7} \mathrm{Be}$ and 1 ithium. As reported in Table $2, .91 \%$ of the ${ }^{7} \mathrm{Be}$ activity remained on the planchette, while $3 \%$. was. retained in the 1 ithium film and approximately $6 \%$ was present in the drained lithium. The ${ }^{7} \mathrm{Be}$ activity in the lithium film was $718 \mathrm{~Bq} / \mathrm{mg}$ as compared with $44 \mathrm{~Bq} / \mathrm{mg}$ of drained lithium. This is a factor of 16 higher for the 1 ithium film, which indicated that ${ }^{7} \mathrm{Be}$ is segregating at capsule walis. Furthermore; the ${ }^{7} \mathrm{Be}$ activity increased with increasing lithium film from bottom to top of the capsule. The average lithium film thickness on the straight 
section of the capsule was computed to be $15.7 \mu \mathrm{m}$. which is slight:ly higher than the $\sim 12 \mu \mathrm{m}$ obtained at $543^{\circ} \mathrm{K}$ in the first set of experiments.

Since the majority of ${ }^{7} \mathrm{Be}$ activity was retained on the planchette in Run $5_{3}$.. an alternate procedure was used for Run 6 . The lithium was heated to $693^{\circ} \mathrm{K}$ for 3 hours and then maintained at $543^{\circ} \mathrm{K}$ for 17 hours. A GeigerMueller counter indicated that much of the activity was still in the vicinity of the planchette. Therefore, the capsule was heated to $838^{\circ} \mathrm{K}$ and keptthere for 5 hours and then maintained at $543^{\circ} \mathrm{K}$ for approximately 17 . hours in an at.tempt to release most of the ${ }^{7} \mathrm{Be}$ from the planchette. Lithium was then drained from the capsule and lithium and $7^{B}$ Be analysis performed:

The results of Run 6 are described in Table 3. It may be noted from Table 3 that our attempt to release majority of ${ }^{7}$ Be activity into lithium was successful. The drained lithium contained $69 \%$ of the original activity on the planchette. The ${ }^{7} \mathrm{Be}$ activity in the 1 ithium film was $25 \%$, while the activity reniaining on the planchette was only $6 \%$. As. for Run 5 , the ${ }^{7} \mathrm{Be}$ concentration of 1 ithium in the lithium film was a factor of $\sim 16$ higher than that in the drained lithium, supportinc our earlier conclusion that. ${ }^{7}$ Be may be migrating toward the capsule walls. An estimate of the lithium. film thickness on the stairiless steel yielded a value of $14 \mu \mathrm{m}$ at $543^{\circ} \mathrm{K}$, which compares favorably. with the data presented above.

. Test Run 7. was performed at $523^{\circ} \mathrm{K}$. . The capsule was heated to $798^{\circ} \mathrm{K}$ and kept at that temperature for $45^{\circ}$ minutes prior to equilibrating at $523^{\circ} \mathrm{K}$ for 17 hours. As pointer out earlier, the high temperature excursion is

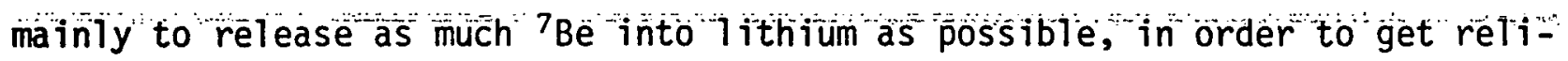
able ? Be-adherence data. Gamma-count data indicated that $16 \%$ of the original ${ }^{7} \mathrm{Be}$ activity remained on the planchette, with $4.1 \%$ of the activity. present in drained lithium, $43 \%$ in the lithium.adhering to the Swagelok fitting and the capsule body. . The ${ }^{7} \mathrm{Be}$ concentration of lithium retained on the capsule was a factor of 71 higher than that in the drained 1 ithium; again substantiating our conclusion that ${ }^{7}$ Be may be migrating towerd the capsule walls. The lithium film thickness on the straight section of the capsule (excluding the Swagelok fitting and the capsule bottom) was computed - as $8.5 \mu \mathrm{m}$ at $523^{\circ} \mathrm{K}$, in excellent agreement with the $8.4 \mu \mathrm{m}$ reported in Table 1 at $515^{\circ} \mathrm{K}$. 
It was not readily apparent from the data presented above if . ${ }^{7} \mathrm{Be}$ actually diffuses into the austenitic stainless steel.

The ${ }^{7}$ Be was mainly contained in the lithium film and was easily washed away with the lithium film, leav-. ing no traces of activity on the walls. To investigate the phenomenon of ${ }^{7}$ Be diffusion more completely, we have performed Run 8 for 4000 hours at. $543^{\circ} \mathrm{K}$.

The results of Run 8 are tabulated in Table 4. ${ }^{7}$ Be could not be removed by methanol/water rinses for segments 6 through $9 .$. . The segments were dissolved in acid $\left(\mathrm{HCL}+\mathrm{HNO}_{3}\right)$ baths to remove ${ }^{7} \mathrm{Be}$ completely. This implies that ${ }^{7} \mathrm{Be}$ actually penetrated into the stainless steel wall. The thickness of stainless steel surface layer removed by the acid was estimated for the segments (Table 6) -by analyzing the solutions for chromium and extrapolating to obtain the mass of stainless steel removed.

The diffusion coefficient (D) of ${ }^{7} \mathrm{Be}$ in alistenitic stainless steel was calculated to be $5.31 \times 10^{-15} \mathrm{~cm}^{2} / \mathrm{sec}$ at $543^{\circ} \mathrm{K}$ from the depth of penetration into segment 6 , assuming $D$ to be independent of composition of steel. Wehave chosen segment 6 due to its proximity to the ${ }^{7} \mathrm{Be}$ source; it is therefore safe to assume that we have a constant source of ${ }^{7} \mathrm{Be}$ from the start of the 4000 -hour experiment. The $\mathrm{D}$ value of ${ }^{7} \mathrm{Be}$ calculated here is much higher than the value of $6.53 \times 10^{-25} \mathrm{~cm}^{2} / \mathrm{sec}$ computed from the diffusion equation derived by Grigoryev and Pavlinov (4) for $D$ of $7 \mathrm{BE}$ in $\gamma$-iron. The difference $i n$ the $O$ values may be explained in the following manner. The equation of reference 4 was derived from the data in the temperature range $1373^{\circ}=1523^{\circ} \mathrm{K}$, and at high temperatures lattice diffusion is important. However, at. lower temperatures; diffusion is mainly through the grain boundaries and grain. boundary diffusion is several orders of magnitude higher than lattice diffusion. In addition, the diffusion of ${ }^{7} \mathrm{Be}$ is expected to be affected by the presence of other alloying elements in steel.

The lithium film thickness for Run 8 was estimated as 10.2 $\mu \mathrm{m}$ at $-543^{\circ} \mathrm{K}$, in good agreement with the data presented here.

\section{(b) MTCL Experiment}

Only one run (Run 1, MTCL) was performed with the MTCL at $543^{\circ} \mathrm{K}$ hot leg and $489^{\circ} \mathrm{K}$ cold leg. The preliminary results are reported here in the following. The data analysis, however, is still continuing. 
As shown in Figure 3, the cold leg vertical section has picked up half. the final equilibrium ${ }^{7} \mathrm{Be}$ activity with in the first 30 hours of MTCL operation. After approximately 300 hours of operation, the 7 Be activity in the cold leg reached a plateau, indicating that the rate of pickup is equal to the rate of decay. The diffusion trap, on the other hand, has reached its plateau of $7 \mathrm{Be}$ activity after approximately the first 100 hours of operation. The final equiTibrium activity in the diffusion trap is less than half the activity found in the cold leg. Very little activity was noted in the hot-leg region, in both the horizontal and the vertical sections. However, buildup of ${ }^{7}$ Be activity was observed at the $90^{\circ}$ elbow between the hot leg and the pump at. levels much higher than in the rest of the hot leg piping. A maximum in ${ }^{7} \mathrm{Be}$ activity was seen in the cold leg about $0.10 \mathrm{~m}(4)$ above the bottom tee (Figure 4). This is the same place where a minimum in temperature was also recorded.. Dur-. ing the operation of the loop, ${ }^{7}$ Be activity under the pump could not be measured due to the interference of the magnetic field generated by the pump coils with the operation of the photomultiplier of the detector...

The MTCL was shut down after 975 hours of operation and 1 ithium drained. Gamma counting of the loop piping, the drained lithium

and the deposition samples was performed. Accounting for decay,-about $93 \%$ of the ${ }^{7} \mathrm{Be}$ activity was present on the piping, $6 \%$ in the drained 7 ithium and $1 \%$ on the deposition samples. Approximately $50 \%$ of the ${ }^{7} \mathrm{Be}$ activity has been accounted for in the vicinity of the ${ }^{7} \mathrm{Be}$ source in the dead-leg piping of the hot leg. Among the deposition samples, iron has picked up the most activity. This is not too surprising since the solubility of beryllium (5) is greater in iron at FMIT temperatures than solutility in cobalt and nickel. "The gamma-counting of the samples was made after removing the lithium film, while the MTCL piping was counted with lithium film in place.

Therefore, on the basis of the capsule experiments, one can say that much of the $93 \%$ of the activity detected on the MTCL piping is quite possibly contained in the lithium film. The lithium film analysis was not carried out for the MTCL piping due to the different temperatures and ? Be activities in different parts of the loop.

.... It is quite possible that the deposition samples. would have-picked up. more. ${ }^{7}$ Be if more was available in the flowing lithium. Run 2, MTCL is currently in progress to check not only the reproducibility of the preliminary data presented here, but also find out if more ${ }^{7} \mathrm{Be}$ could be deposited onto the samples. The ${ }^{7} \mathrm{Be}$ source for the second run is located in flowing lithium in the hot leg, upstream from the deposition samples. 


\section{CONCLUSIONS}

It can be concluded from the present investigations that ${ }^{7} \mathrm{Be}$ adheres to the steel wall in contact after prolonged exposure time at FMIT. temperatures, and has a tendency to segregate to the cold leg of : the loop.: The diffusion trap has been shown to be ineffective under conditions of very. small flow rates. Very 1 ittle ${ }^{7}$ Be activity can be removed by draining the lithium from the loop after prolonged operation. This means that control methods must be developed to isolate ${ }^{7} \mathrm{Be}$ in parts of the loop that can be removed and replaced for easy contact maintenance of FMIT. - Experiments are currently underway to investigate the effect of doping the hot leg lithium with inert beryllium to precipitate ${ }^{7} \mathrm{Be}$ in the cold leg. dditional experiments with deposition samples are also continuing to verify the reproducibility of the data presented here and to develop a trap material for ${ }^{7} \mathrm{Be}$.

\section{ACKNOWLEDGMENTS}

The authors wish to express their gratitude to Mr. H. P. Maffei for setting up the multichannel analyzer for gamma counting. 


\section{REFERENCES}

1. Final Environmental Impact Statement, Fusion Materials Irradiation Testing Facility, Hanford Reservation, Richland, Washington, DOE/EIS-77; Apri1. 1978.

2. J.: 0. Cowles and A. D. Pasternak, Lithium Properties Related to Use as a Nuclear Reactor Coolant, UCRL-50647, Lawrence Radiation Laboratory.

3. B. Longson and J. Prescott, Liquid Alkali Metals, Proceedings of theInternational Conference Organized by the British Nuclear Energy Society, p. 171, April 1973.

4. G. V. Grigoryev and L..V. Pavlinov, Fiz. Metal. Metalloved., 25, No. 5, p. $836,1968$.

5. M. Hansen and K. Anderko, Constitution of Binary Alloys, McGraw-Hill, New York, 1958. 
TABLE 1. LITHIUM FILM THICKNESS MEASUREMENTS

\begin{tabular}{ccc} 
Run \# & $\cdots$ & $\begin{array}{c}\text { Temperature } \\
{ }^{\circ} \mathrm{K}\end{array}$ \\
\hline 1 & 515 \\
2 & 537 \\
3 & 495 \\
4 & 571
\end{tabular}

Average Lithium Film Thickness ( $\mu \mathrm{m})$

8.4

11.1

12.2

12.3 
TABLE 2. RESULTS OF RUN $5\left(543^{\circ} \mathrm{K}\right)$ WITH ${ }^{7}$ Be

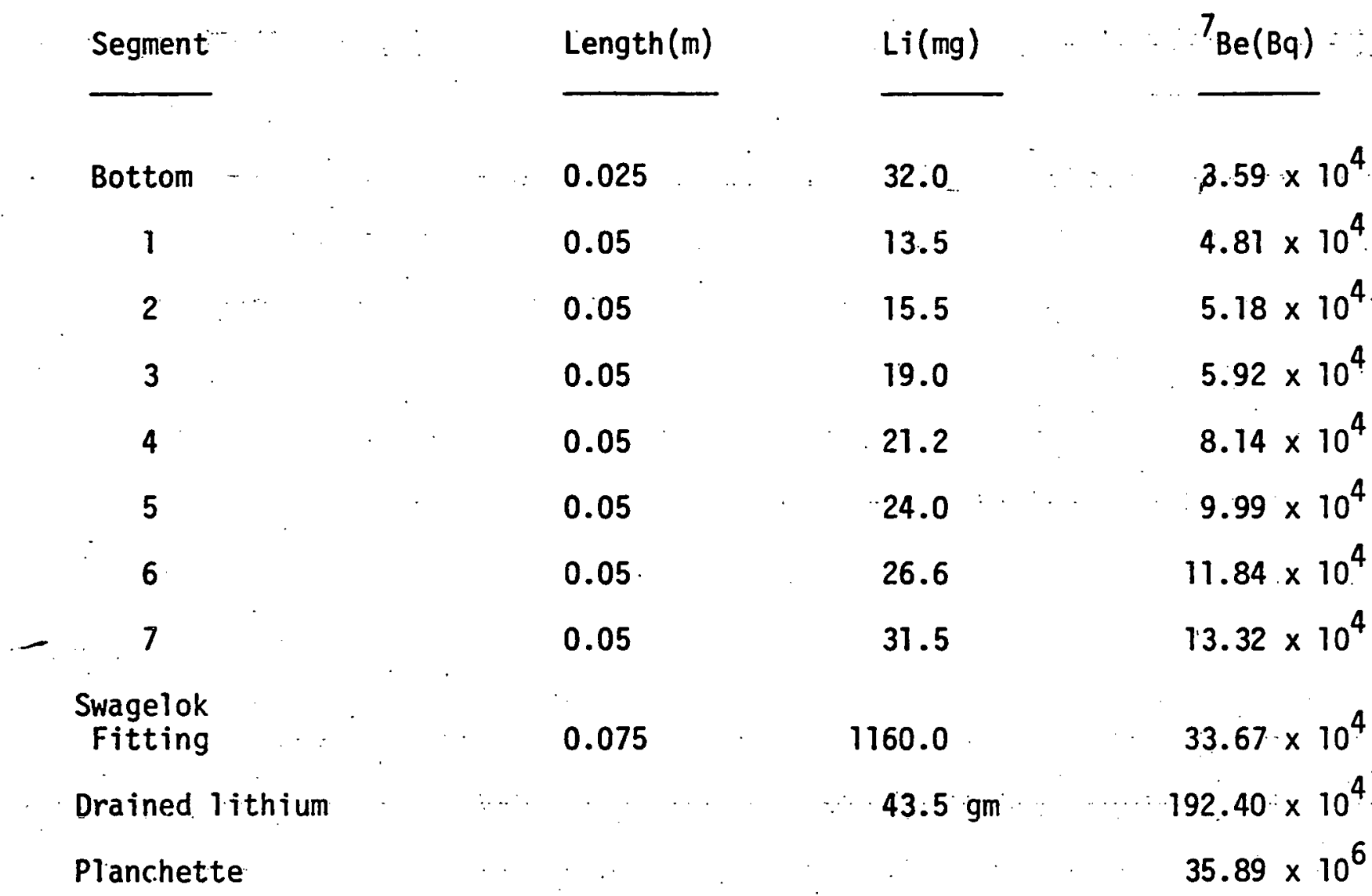




\section{TABLE 3. RESULTS OF RUN $6:\left(543^{\circ} \mathrm{K}\right)$ WITH ${ }^{7} \mathrm{Be}$}

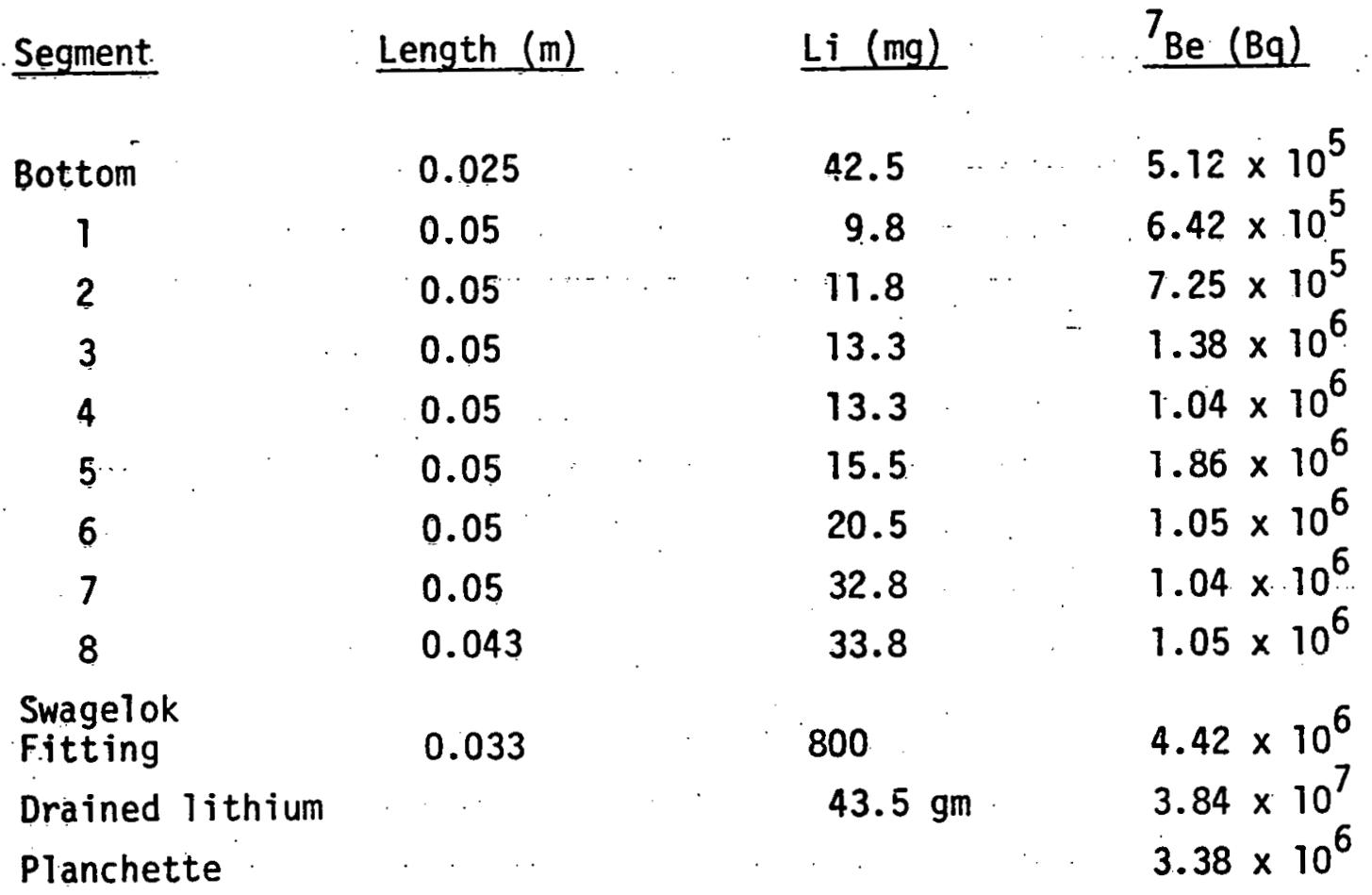


TABLE : 4.. RESULTS OF 4000 -HOUR ? Be TEST AT $543^{\circ} \mathrm{K}$

\begin{tabular}{cccc} 
Segment & Length(m) $\cdots$ & Steel Removed $(\mathrm{mg})$ & $\begin{array}{c}\text { Depth of }{ }^{7} \mathrm{Be} \\
\text { Penetration } \\
(\mu \mathrm{m})\end{array}$ \\
\cline { 2 - 4 } & 0.051 & 122 & 5.53 \\
7 & 0.051 & 101 & 4.58 \\
8 & 0.051 & 31 & 1.41 \\
9 & 0.038 & 9 & 0.54
\end{tabular}




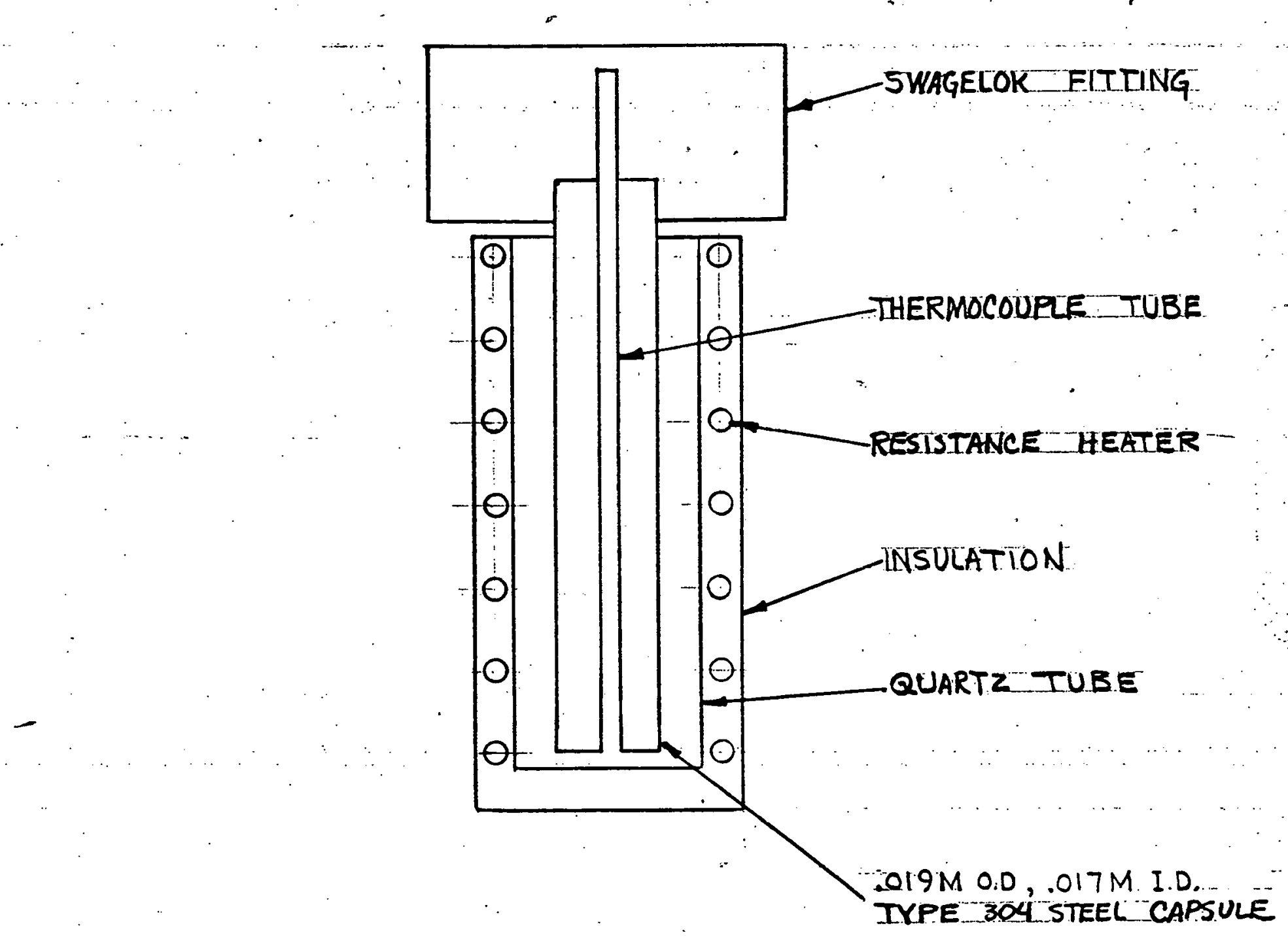

FIGURE 1 : SCHEMATIC OF CAPSULE ARRANGEMENT 


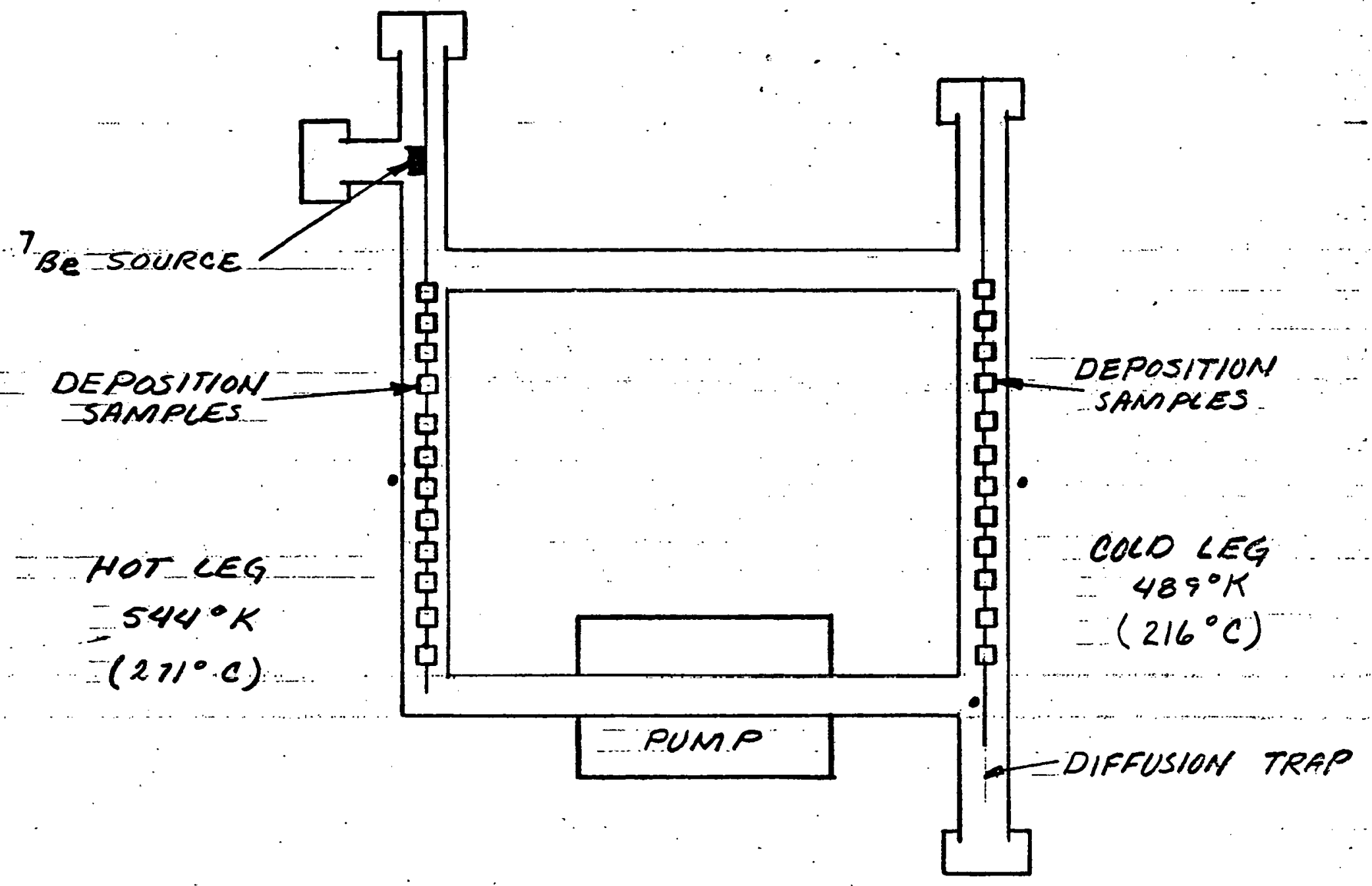

FIGURE 2. MODIFIED THERMAL CONVECTION LOOP SCHEMATIC. 


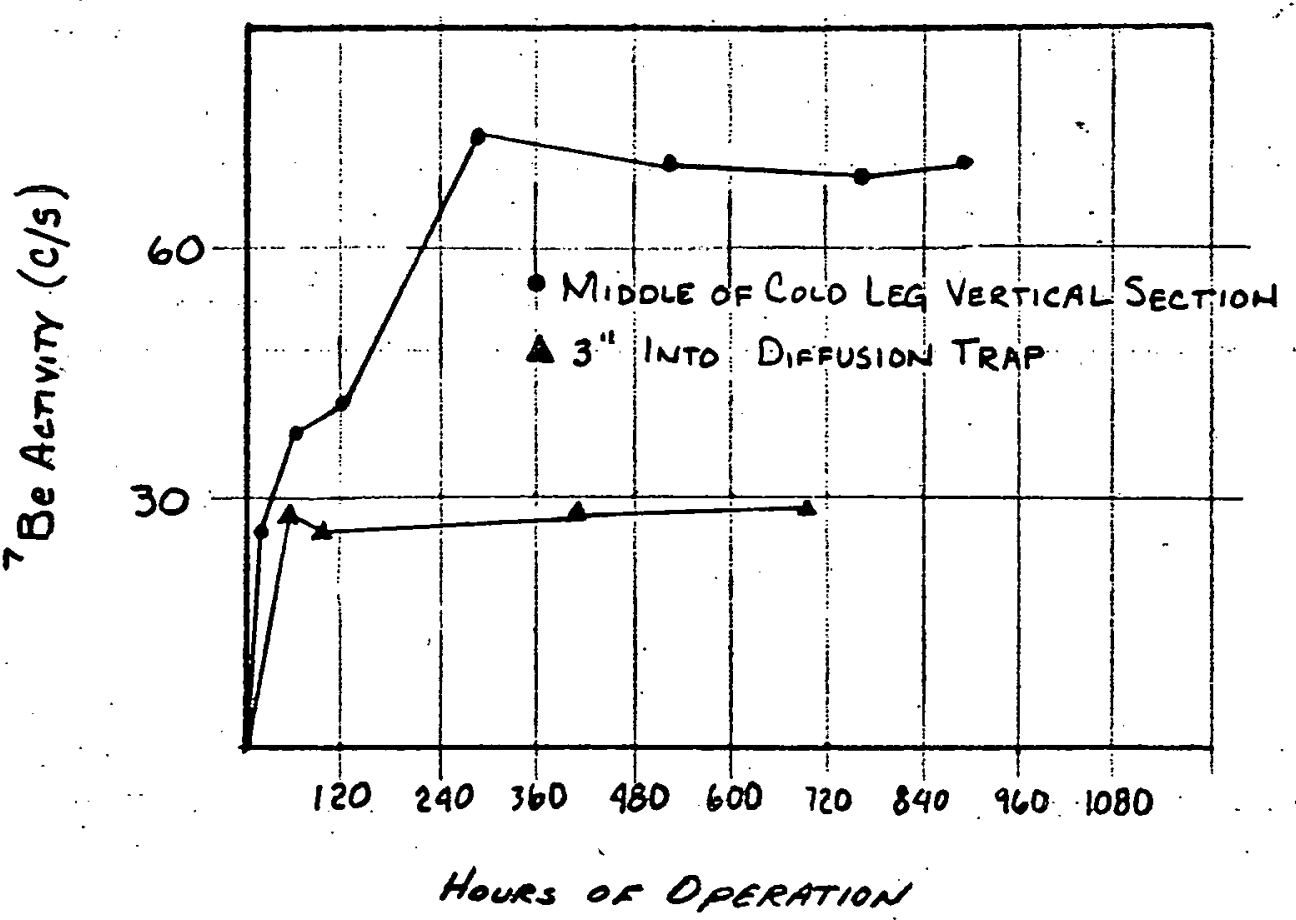

FIGURE 3. ${ }^{7}$ Be DISTRIBUTION DURING MTCL OPERATION 


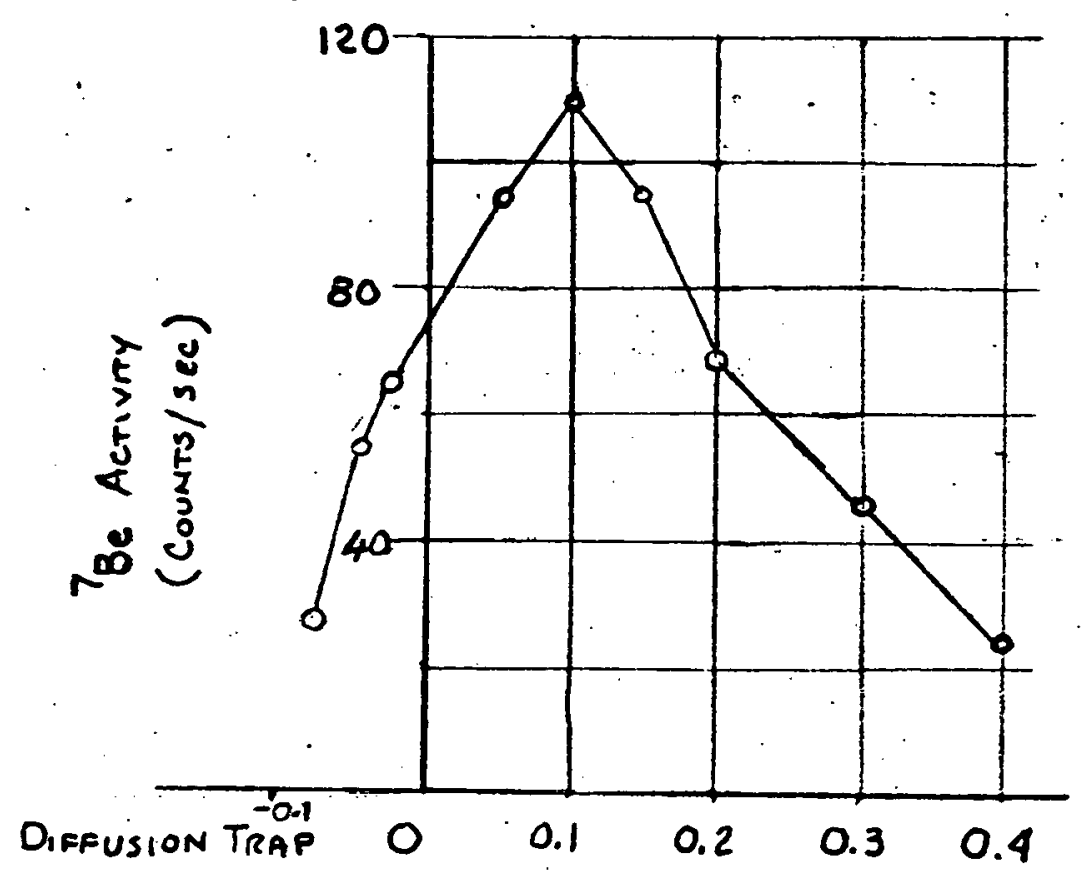

Distance along colo leg vertical section (METERS)

Figure 4. ${ }^{7}$ Be DISTRIBUTION IN MTCL COLD LEg AFTER APPROXIMATELY. 300 HOURS OF OPERATION - TEMPERATURE ( $\sim 483^{\circ} \mathrm{K}$ ) 
MATEFIAL TO BE PRESENTED AT THE POSTER SESSION 


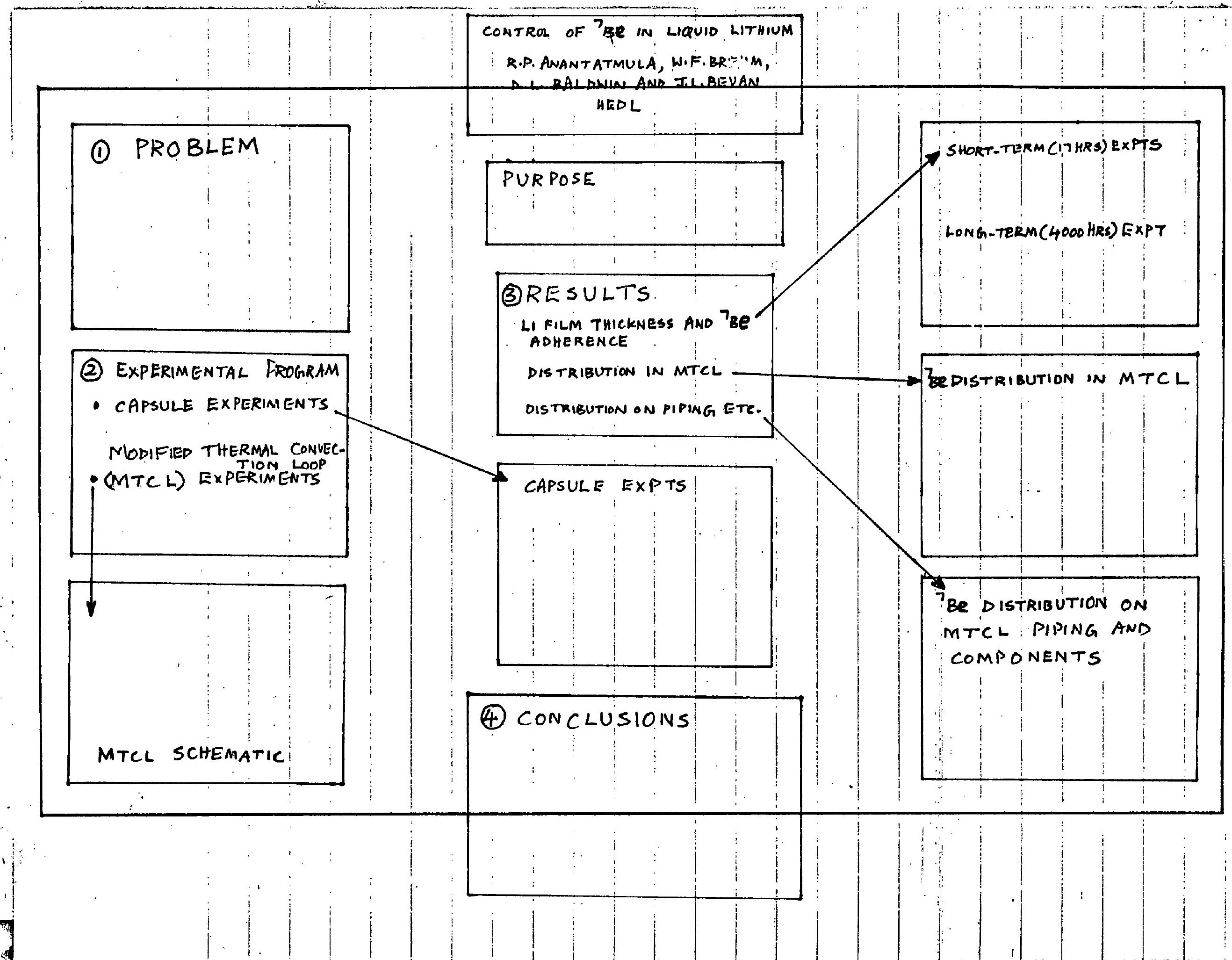




\title{
CONTROL OF BERYLLIUM-7 IN LIQUID LITHIUM
}

\author{
$R . P$, ANANTATMULA, W. $F$, BREHM, $D, L$, BALDWIN AND J. L. BEVAN
}

HANFORD ENGINEERING DEVELOPMENT LABORATORY 


\section{PURPOSE}

- TO DEVELOP A METHOD TO CONTROL THE TRANSPORT OF ${ }^{7}$ Be IN FUSION MATERIALS IRRADIATION TEST (FMIT) FACILITY 
(1) PROBLEM

- 7 Be WILL BE PRODUCED IN FMIT LITHIUM TARGET BY INTERACTION OF DEUTERON BEAM WITH LITHILM

- RECENT ESTIMATES SHOW THAT AN EQUILIBRIUM CONCENTRATION OF AT LEAST $2.59 \times 10^{15}$ BQ OF 7 BE WILL BE PRESENT IN FMIT LITHIUM

- THIS CONCENTRATION OF ${ }^{7}$ Be LEADS tO RADIATION FIELDS OF OVER $5.16 \times 10^{-3}$ COULOMB/KG. HR (20 R/HR) PREVENTING CONTACT MAINTENANCE OF FMIT PIPING AND COMPONENTS 
(2) EXPERIMENTAL PROGRAM

- CAPSULE EXPERIMENTS

TO DETERMINE LITHIUM FILM THICKNESS ON AND 7 BE ADHERENCE TO

STAINLESS STEEL AT FMIT TEMPERATURE $\left(473^{\circ}-573^{\circ} \mathrm{K}\right)$

- MODIFIED thERMAL CONVECTION LOOP (MTCL) EXPERIMENTS (HOT LEG $543^{\circ} \mathrm{K}$; COLD LEG $489^{\circ} \mathrm{K}$ )

TO IDENTIFY 7 BE TRANSPORT IN A TEMPERATURE GRADIENT

TO TEST EFFECTIVENESS OF DIFFUSION TRAP IN PICKING UP. ${ }^{B}$ BE IN SLOWLY FLOWING LITHIUM

1: TO DETERMINE THE ABILITY OF FE, CO AND NI SAMPLES IN GETTERING ${ }^{7} \mathrm{BE}$. 
CAPSULE EXPERIMENTS

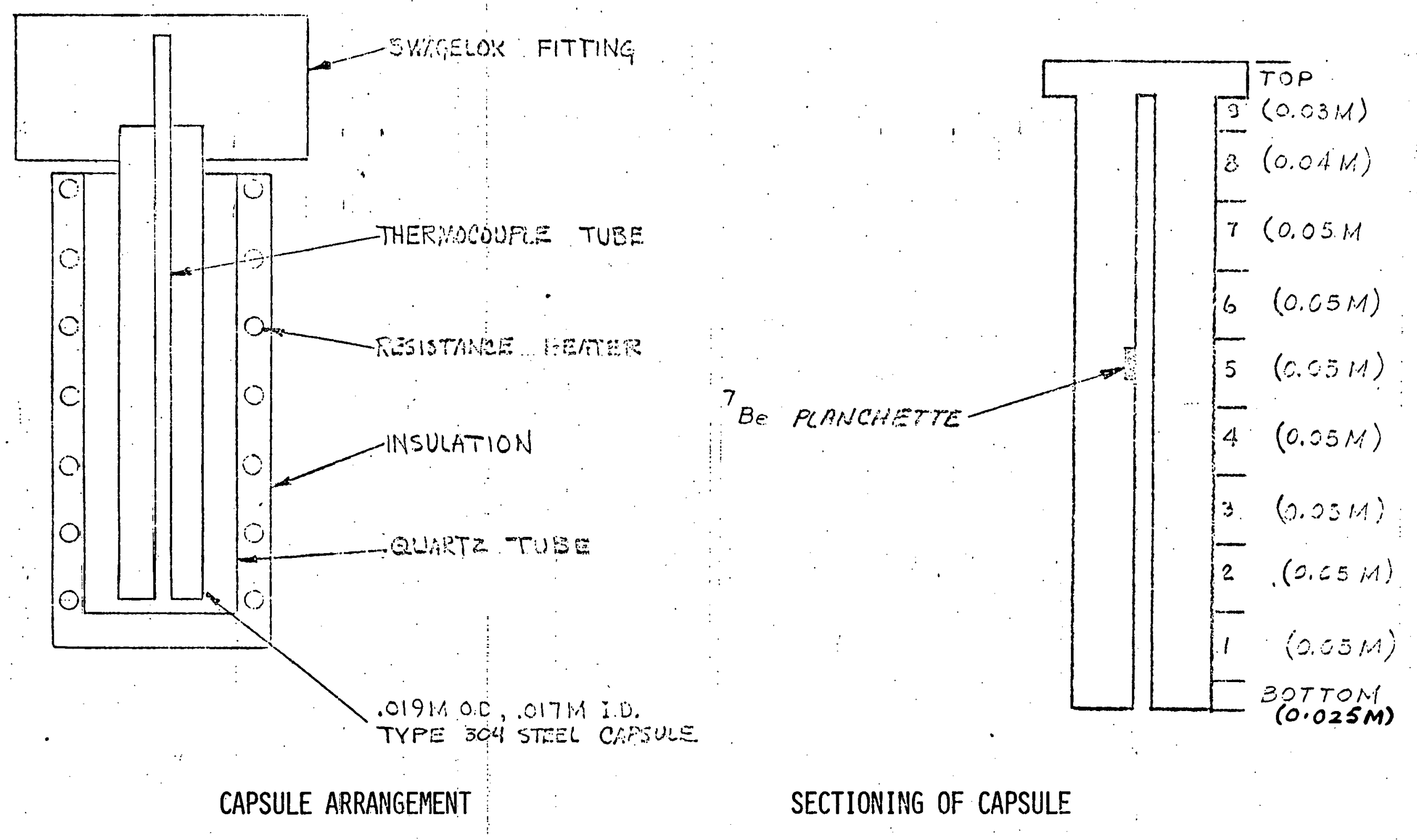


- THERHOCWHER lOCHTHON

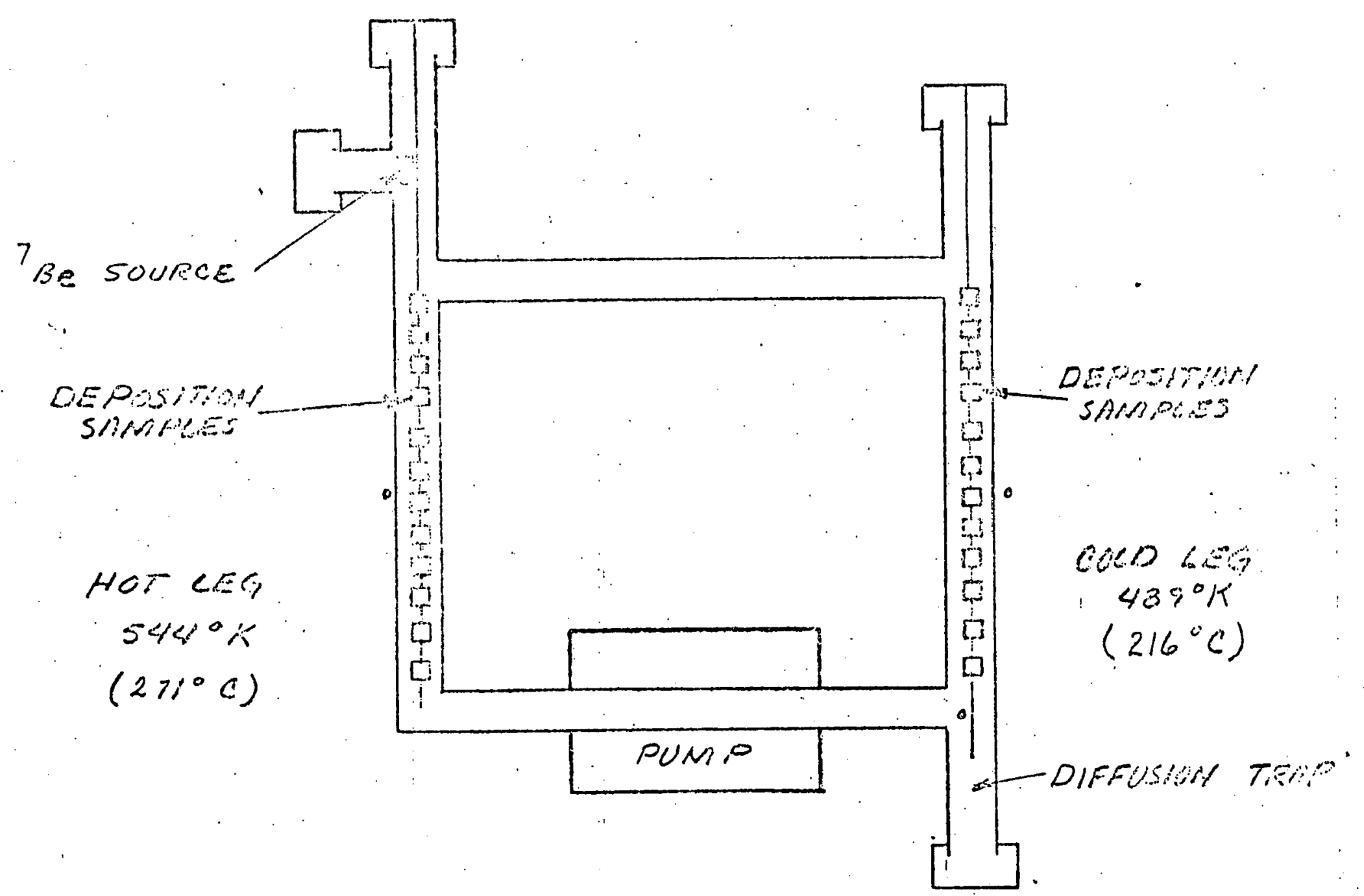




\section{(3) RESULTS}

- LithiUm FILM THICKNESS AND 7 Be ADHERENCE

- Distribution OF ${ }^{7}$ Be IN MTCL dURing operation

- distribution of ${ }^{7}$ Be ON MtCl piping and Components 
LITHIUM FILM THICKNESS AND $7_{\text {BE ADHERENCE MEASUREMENTS }}$

- SHORT-TERM EXPERIMENTS (17, 24 HRS)

- AVERAGE LITHIUM FILM THICKMESS IS 11 uM IN THE TEMPERATURE RANGE $495^{\circ}-571^{\circ} \mathrm{K}$

- 7Be PREFEREnTIALly Migrates to CAPSULE WALL

- LONG-TERM EXPERIMENT ( 4,000 HRS)

- 7 BE PENETRATES INTO THE STAINLESS STEEL CAPSULE WALL AT: FMIT TEMPERATURES

- DIFFUSION COEFFICIENT OF 7BE IN STEEL $5.31 \times 10^{-15} \mathrm{~cm}^{2} / \mathrm{SEC}$ AT $543^{\circ} \mathrm{K}$ 


\section{Be DISTRIBUTION IN MTCL (DURING OPERATION)}
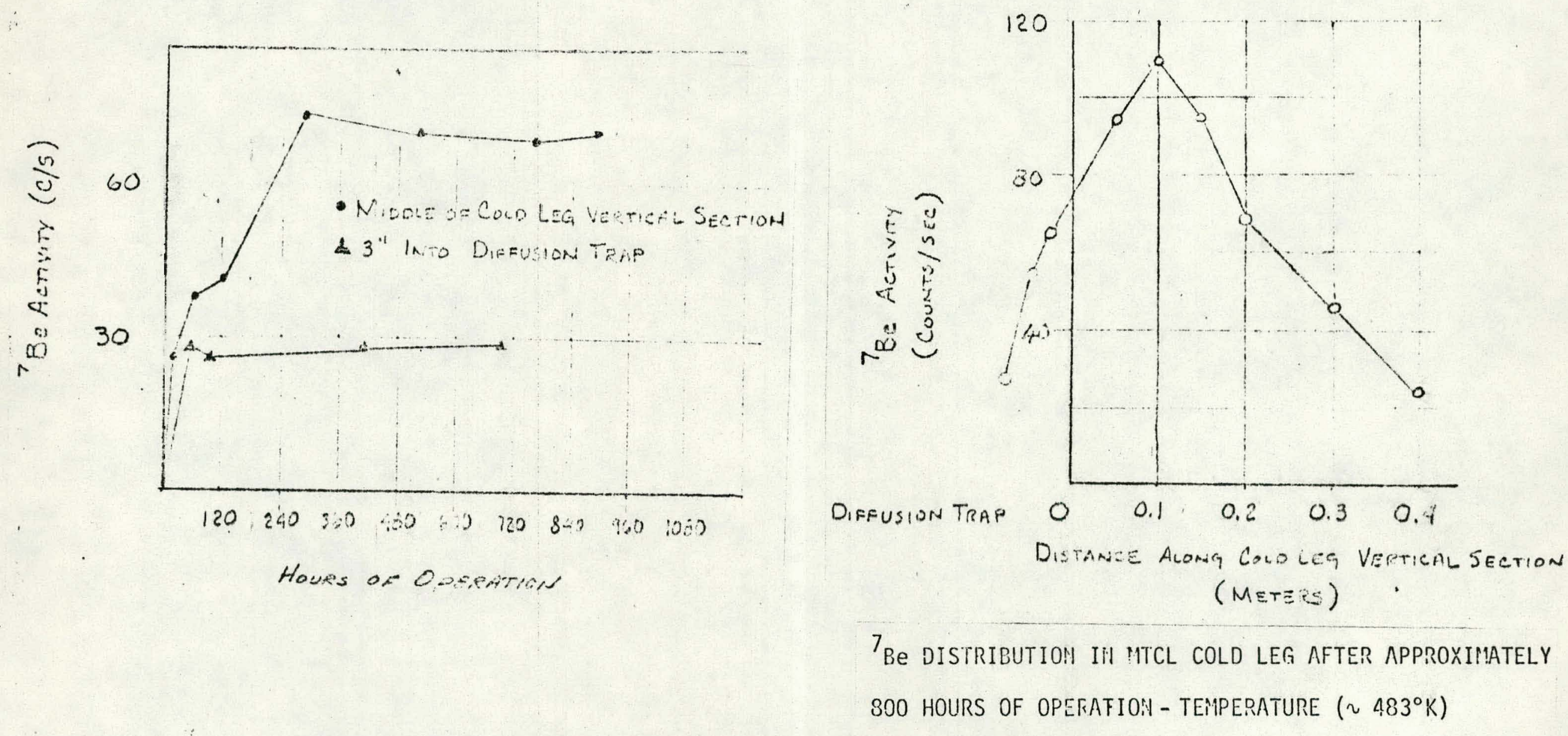


\section{Be DISTRIBUTION ON MTCL PIPING AND COMPONENTS}

(AFTER 975 HRS OF OPERATION)

- $93 \%$ OF 7 Be ACTIVITY PRESENT ON PIPING

$\therefore \quad 50 \%$ PRESENT IN : THE VICINITY OF $\overline{7}_{\text {Be SOURCE }}$

- $6 \%$ of ${ }^{7}$ Be Activity PRESENT IN DRAined Lithium

- $1 \%$ OF 7 Be ACTIVITY PRESENT ON DEPOSITION SAMPLES

- IRON SAMPLES PICKED UP MORE ACTIVITY COMPARED WITH COBALT AM:D NIEKEL SAMPLES 
(4) CONCLUSIONS

- 7 Be ADHERES TO STAINLESS STEEL AFTER PROLONGED EXPOSURE AT FMIT TEMPERATURES

- 7Be SEgREGATES TO THE COLD LEG OF A LITHIUM LOOP

- DifFUSION TRAP IS NOT VERY EFFECTIVE IN REMOVING 7Be FROM LITHIUM AT LOW FLOW RATES

- Very little 7 Be CAN Be removed by dRAinimg Lithium FROM THE LOOP AFTER PROLONGED OPERATION

- CONTROL METHODS MUST BE DEVELOPED TO ISOLATE 7 Be IN PARTS OF THE LOOP THAT CAN BE REMOVED AND REPLACED 